\title{
EMPIRICAL ESTIMATION OF MONETARY POLICY IFLUENCE ON STOCK EXCHANGE INDICATORS
}

The purpose of the current research is to conduct the empirical analysis and develop adequate econometric instruments for estimation of the relationship between monetary indicators and stock exchange indices in order to determine the effective instruments for stock exchange market development in the short and long runs. During the research the following methods have been used: general scientific methods of system analysis and synthesis; generalization, systematization and grouping of data; modern economic and mathematical instruments, in particular, methods of vector autoregression.

Study results. The conducted statistical analysis and the realization of developed econometric VAR/ $V E C M$ models using the real data allowed us to estimate the potential capability of state regulators to influence the development of stock exchanges in different groups of countries as well as to develop the most effective monetary instruments of stock exchange stimulation while taking into account internal and external risks in the short and long runs.

The results of this research paper can be used when making management decisions by state regulators on the ways of stimulation of stock exchanges development in different groups of countries, in particular Ukraine.

Conclusions. Based on the conducted research using the system of developed VAR/VECM models, it was empirically proven that the central bank and other regulators can actually influence stock exchange indices using monetary instruments, but this influence is only significant on the markets of developed countries (e.g., the USA). However, in developing countries the stock exchange index does not depend on short-term changes of monetary indicators, which decreases the power of regulators to affect the stock exchange indices. At the same time, stock exchange indices are significant factors that influence monetary indicators not only in developed countries (the USA) but also in developing ones (Ukraine, Poland). Taking into consideration the results of the current research, it can be deduced that the economy of Ukraine is still in the transition phase and is characterized by significant political and economic risks, while the monetary policy of the regulator is rather an ineffective instrument to control and regulate the capital markets. In addition, the development of stock exchange markets has a positive impact on macroeconomic indicators of the developing economy. That is why the development of the effective and liquid stock market is a highly important element of Ukrainian state economic policy, which can become one of the main factors of its economic growth in mid-and long runs.

Keywords: monetary policy, stock market, macroeconomic indicators, vector autoregression models, vector error correction models

\section{JEL classification: E52, E59, C32}

Introduction and research problem. In order to achieve a considerable and sustainable economic growth, a country usually needs effective functioning of stock exchanges that provides not only an opportunity to allocate and attract a significant amount of financial resources, distribute and redistribute the capital but also plays an important informational role. Basically, in developed countries and countries with rapid economic growth a significant influence on stock exchanges development is conducted through monetary policy instruments, which is not always true for countries with large economic and political risks, e.g. Ukraine. Accordingly, taking into consideration significant economic and political risks as well as a low level of capital markets development in Ukraine, it is highly important to conduct a thorough analysis regarding the ways of stimulating the stock exchanges development in Ukraine, in particular using monetary instruments. It should be noted that the empirical study and verification of the relationship between monetary indicators and stock exchange indices for different economies is beneficial in several ways: it helps in revealing the potential opportunities of state regulators to influence the stock exchanges development through monetary instruments as well as to determine for which economies current approach is the most relevant and which stimulating monetary instruments are the most effective and efficient for each distinct country, including Ukraine.

Conducting such a thorough analysis needs, in turn, the development of adequate econometric 
instruments for different groups of countries taking into consideration peculiarities of their economic development. This is why the vector autoregression and vector error-correction models may be useful for respective purposes.

Recent publications analysis. The problem of the relationship between macroeconomic variables and stock indices was actively investigated by foreign and Ukrainian scientists during the last decades. In fact, research of western scientists has been focused mainly on the markets of the most developed and prosperous countries, in particular the USA, as well as countries with rapid economic growth. For instance, the comprehensive study of A.A. Rad on the interaction between macroeconomic factors and stock exchange indices in developed and developing countries helped to generalize the view of many scientists that stock prices in these economies are defined by particular macroeconomic variables, including interest rates, exchange rates, the level of inflation, and money supply [15]. Other foreign researchers, in particular K. Chadhuri and S. Smiles, also believe that in financial literature there is lots of evidence that changes in share prices are tightly related to changes in macroeconomic factors, which is also confirmed by their empirical studies for the markets of Australia, the USA, and New Zealand [11]. In addition, a strong relation between stock indices and macroeconomic variables is supported by numerous events in historical retrospective. According to I. Oseni, P. Nwosa, global experience confirms the fact that stock markets have always played a crucial role in economic and political development of countries [14]. Studies of many Ukrainian scientists, in particular S. Hlushchenko, K. Klymenko, I. Krasnova, V. Popko, O. Primierova, O. Chernova, and S. Shumska are dedicated to the research of interplay between stock exchange indicators and macroeconomic variables reflecting the economic development in different countries [1, 3, 6, 9]. Recently there has also been an increasing number of scientific studies on interrelation between macroeconomic and stock exchange indicators using economic and mathematical methods of different complexity. The problems related to modelling of processes observed on stock markets, in particular stock market bubbles, estimation of financial imbalances and their influence on economic growth are examined in the studies of such researchers as V. Heits, T. Klebanova, I. Lukianenko, R. Semko, M. Skrypnychenko, O. Chernyak, S. Shumska and others [2, 5, 7, 8, 10].

In the works of V. Heits, M. Skrypnychenko, and S. Shumska econometric sectoral macromodels are used [5,10]. For similar research, I. Lukianenko, R. Semko, and O. Chernyak use dynamic stochastic general equilibrium models as well as longitudinal (panel) data models [2,7,8]. Foreign scientists, including B. Lee, Y. Cheung, and L. Ng, actively use mathematical time series apparatus, e. g. vector autoregression models. The results of their research regarding the markets of Canada, Germany, Italy, Japan, and the USA also confirmed the existence of significant relation between stock exchange indices and macroeconomic variables in the long run $[12,13]$.

Unsolved parts of the problem. The analysis of works of Ukrainian and western scientists takes to the following conclusion. Despite a sufficient amount of theoretical and empirical studies regarding the formation and development of stock exchanges, the analysis of relationship between monetary policy and stock indices was quite fragmentary, especially for the countries with significant political and economic risks. That is why the current topic needs further elaboration using econometric and mathematical instruments.

Research goal and questions. The purpose of the research is the empirical analysis and development of an adequate set of econometric tools for estimation of the relationship between monetary indicators and stock market indices for different groups of countries, verifying the potential ability of state regulators to influence the stock market development, using monetary instruments.

To achieve the purpose, the following objectives need to be completed: to make initial assumptions regarding the interrelation between monetary and stock market variables and define the approaches to test this relation; to develop a system of vector autoregression models, including vector error-correction models; to estimate this relationship for different groups of countries and define the monetary instruments that effectively and efficiently stimulate the development of stock exchanges in the short and long runs.

Main findings. To detect and estimatethe the relationship between monetary indicators and stock indices for different countries, as well as to inspect the ability of state regulators to significantly influence the stock exchange development using monetary policy instruments, a system of vector regression models was developed, taking into consideration economic peculiarities of each group of countries. A preliminary comprehensive statistical and empirical analysis helped to define the typical representatives of each group of countries, in particular the USA for developed countries, Poland for successfully developing economies, and Ukraine as a developing country with significant political and economic risks. It should be mentioned that vector autoregression models (VAR/VECM) are effective instruments for relationship investigation between multivariate time series because they provide robust 
forecasts using minimal amounts of input data and help to analyse the reaction of key variables on external and internal shocks.

Vector Autoregression Model (VAR) of the order $p$ can be presented in the following generalized form:

$\left[\begin{array}{c}Y_{1 t} \\ \ldots \\ Y_{n t}\end{array}\right]=\left[\begin{array}{c}A_{10} \\ \ldots \\ A_{n 0}\end{array}\right]+\left[\begin{array}{ccc}A_{11}(L) & \ldots & A_{1 n}(L) \\ \ldots & \ldots & \ldots \\ A_{n 1}(L) & \ldots & A_{n n}(L)\end{array}\right]\left[\begin{array}{c}Y_{1, t-1} \\ \ldots \\ Y_{n, t-p}\end{array}\right]+\left[\begin{array}{c}\varepsilon_{1 t} \\ \ldots \\ \varepsilon_{n t}\end{array}\right]$

where $A_{i o}-$ unknown constants in each equation of the VAR system; $A_{i j}(L)$ - the polynomial of the lag operator of the order $p ;\left\{Y_{j t}\right\}-$ a vector of endogenous variables; $\left\{\varepsilon_{j t}\right\}-$ a vector of innovations; $j=1,2, \ldots, n ; i=1,2, \ldots, n ; \mathrm{t}=1,2, \ldots, T$.

A special subgroup of VAR is composed of vector error-correction models (VECM). The main difference of VECM is that they are used in case of existence of cointegration equation that describes the long-term equilibrium relationship between variables under analysis, while the identical to VAR part characterizes the short-term shocks (divergence from long-term equilibrium in dynamic). It should beconsidered that an essential precondition for the existence of cointegration relation is the same and non-zero order of variables' integration. A simplified version of the long-run equilibrium equation, in the case when endogenous variables are nonstationary of the order one $(I(1))$ and are cointegrated, can be written as follows:

$u_{t-1}=Y_{1, t-1}-\gamma_{0}-\gamma_{1} Y_{2, t-1}-\ldots-\gamma_{n} Y_{n, t-1} \sim I(0)-$ an equation of the long-run equilibrium (cointegration equation); $u_{t-1}-$ deviation from the long-run equilibrium (white noise). It should be considered that an essential precondition for the existence of cointegration relation is the same and non-zero order of variables' integration.

Respective and distinct VAR/VECM models were built for the USA (as a proxy for developed countries), Poland (a representative of actively developing countries); and Ukraine (as a proxy for developing economy with significant economic and political risks). In addition, based on the conducted comprehensive preliminary analysis, the following main variables were included to the system of VAR/ VECM models: M3 aggregate as a proxy-variable for money supply indicator (MSUPPLY) that fully reflects money in circulation, as well as money on bank accounts of private individuals and legal entities. The variable of exchange rate (XCH_RATE) represents a nominal currency exchange rate of Polish zloty and Ukrainian hryvnia to US dollars. For inflation variable (CPI), a relative consumer price index was chosen as the most widely-used indicator of inflation. Units of measurement - index (base 2010). As a proxy-variable for interest rate (IRATE) a long-term interest rate was selected that reflects the average value of money with a long-term horizon. A variable of reserves (RESERVES) describes the amount of official currency and gold reserves of the National Bank of Ukraine. As proxies for stock exchange index (FINDEX) three respective indices were accepted - NYSE Composite for the US model, WIG - for modelling the economy of Poland; and PFTSI - for Ukraine.

Modelling and all calculations were conducted based on the actual monthly data from June 2002 to February 2017, using econometric and data science tools, mainly E.Views and RStudio.

During the first stage of modelling, a vector autoregression model of the US economy was developed. The model consists of 4 equations with 3 lags that reflect the interplay between the indicators mentioned above. It should be noted that the model for the US economy does not include an exchange rate variable because the nominal exchange rate is calculated relatively to the US dollars.

Taking into account the notation described above, the estimated VAR-model based on the actual data, which explains the interrelation between monetary and stock exchange indicators, is presented in the following form (t-statistics are given in parentheses):

$$
\begin{aligned}
& C P I_{t}=1.296 C P I_{t-1}-0.4 C P I_{t-2}+0.09 C P I_{t-3}-0.005 I N T R A T E_{t-1}- \\
& (13.94)(-2.99) \quad(1.11) \quad(-0.59) \\
& -0.005 \text { INTRATE }_{t-2}+0.009 \text { INTRATE }_{t-3}+0.507 M O N E Y_{-} S U P P L Y_{t-1}- \\
& (-0.58)(0.69)(1.96) \\
& -0.75 M O N E Y \_S U P P L Y_{t-2}+0.24 M O N E Y_{-} S U P P L Y_{t-3}- \\
& (-1.89)(0.91) \\
& -0.065 N Y S E_{-} I N D E X_{t-1}+0.13 N Y S E_{-} I N D E X_{t-1}- \\
& (-2.59)(3.8) \\
& -0.049 N Y S E_{-} I N D E X_{t-3}-0.0133 \\
& (-1.92)(-0.16)
\end{aligned}
$$




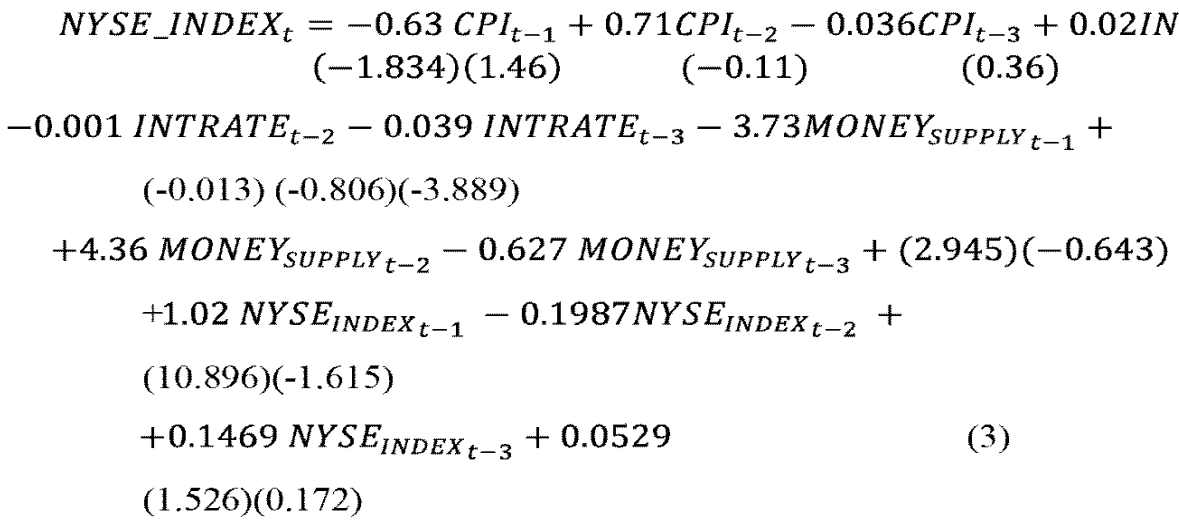

It should be noted that only the equations of consumer price index (CPI) and stock index (NYSE INDEX) were chosen from the general estimated model for presentation purposes.

According to the results of the conducted calculations, the changes in CPI are mainly influenced by the lagged values of CPI and the lagged values of stock exchange index, which also has an influence on the changes in interest rate. Money supply is impacted by lagged variables of CPI as well as lagged values of stock exchange index, while stock index (NYSE_RATE), in turn, is significantly impacted by money supply as well as the lagged values of the stock index itself. In addition, the analysis of impulse response functions, presented in Fig. 1, demonstrates that after a shock of one standard deviation, most variables rapidly increase after the second or third periods (e.g. CPI and money supply in response to the CPI shock; interest rate and stock index in response to the shock from the interest rate), or promptly decrease their values after the second period (stock index in response to the shock from CPI).

Besides, the analysis of variance decomposition revealed that, for instance, $55 \%$ of stock index (NYCE_RATE) variation is explained by previous values of this index, $30 \%$ on average can be explained by changes in CPI, and the rest - by other variables.

The analysis of the model's results confirms the initial assumption that in case of a developed economy (the USA), the stock index is not only impacted by monetary variables but also, in turn, significantly influences the indicators of the monetary policy.

While constructing the econometric model to estimate the interrelation between monetary policy instruments and stock exchange indicators for Polish economy, the statistical test on stationarity of respective time series was conducted. The test demonstrated that all variables under analysis are stationary in first differences. Besides, there exists a cointegration relationship between variables, which was revealed by Johansen test. It means that vector error-correction model (VECM) is needed for Polish economy (the model consists of 5 equations with lags of 1).

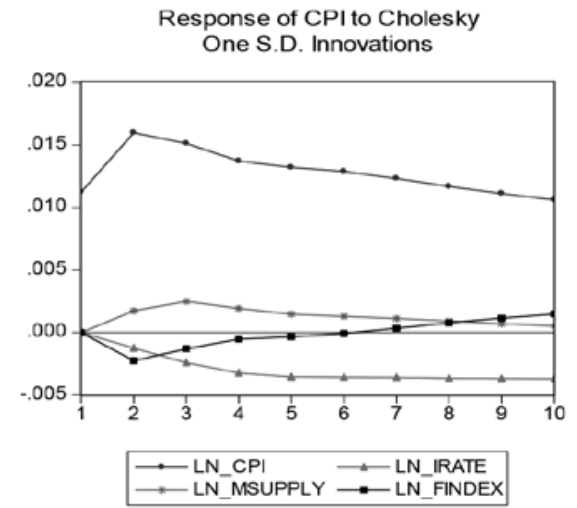

Response of MONEY_SUPPLY to Cholesky One S.D. Innovations

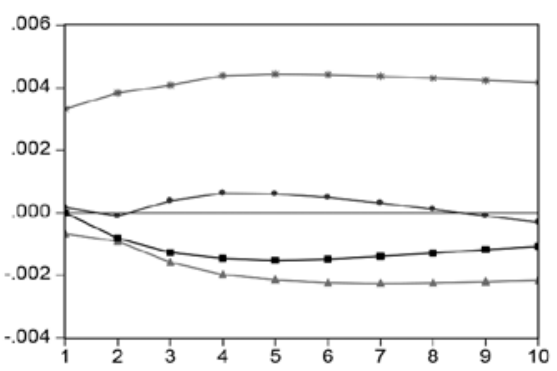

$\because$ LN_CPI $\because$ LN_IRATE

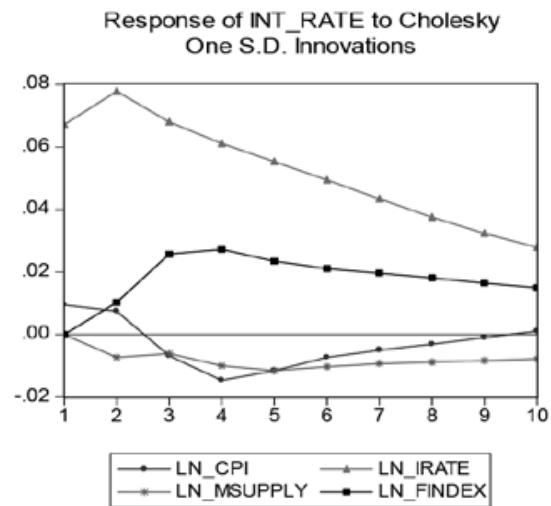

Response of NYSE_INDEX to Cholesky One S.D. Innovations

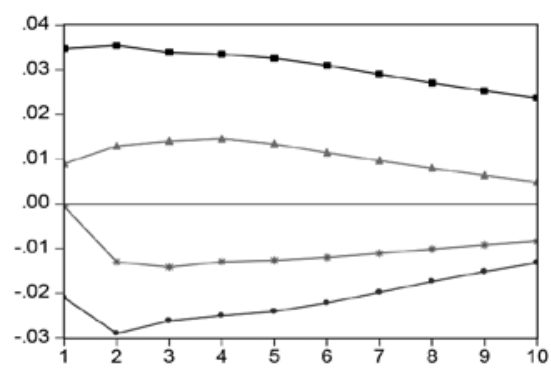

\begin{tabular}{l}
$\because$ LN_CPI \\
$\because$ LN_MSUPPLY $\because-$ LN_IRATE \\
\hdashline LINDEX
\end{tabular}

Fig. 1. Graphs of impulse response functions to one standard deviation shock of the following variables: consumer price index (CPI), interest rate (IRATE), money supply (MONEY SUPPLY), stock exchange index (FINDEX)

(Source: calculated by the authors) 
Taking into account the notation presented above, the estimated VECM model based on the actual data, which describes the interplay between monetary policy instruments and stock market index, is constructed in the following form ( $\mathrm{t}$ - statistics are presented in parentheses):

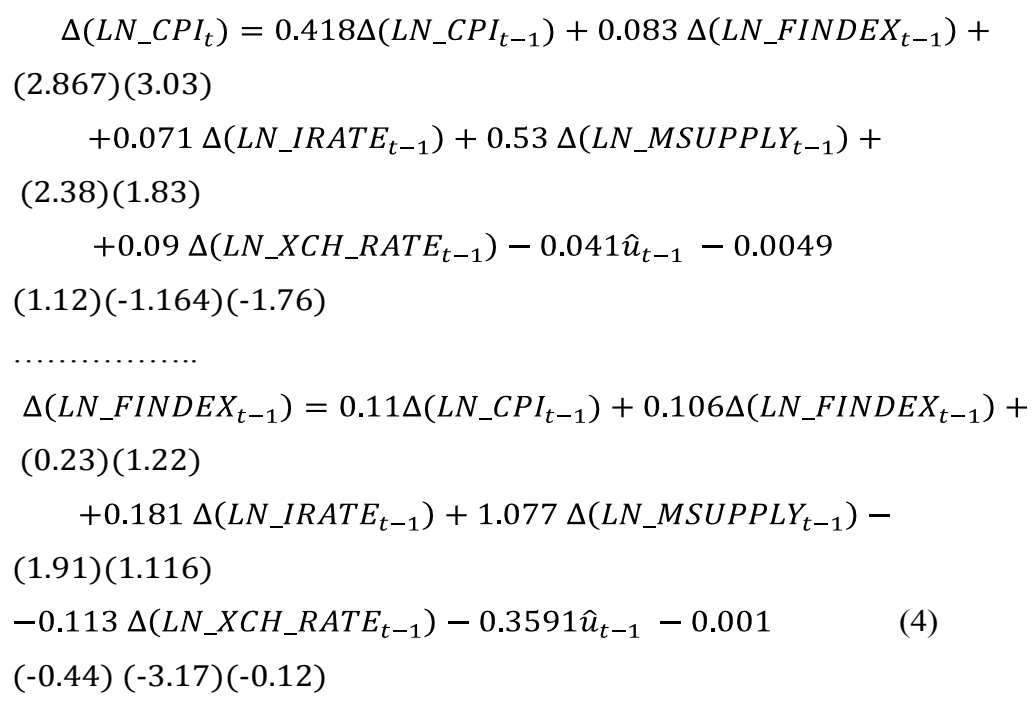

where $u_{t-1}-$ the equation of long-term equilibrium (cointegration equation) normalized by CPI variable. The equation is presented in the following form:

$$
\begin{gathered}
\hat{u}_{t-1}=L N \_C P I_{t-1}-0.103 L N_{-} F I N D E X_{t-1}-0.07 L N I R A T E_{t-1}+ \\
+0.071 L N \_M S U P P L Y_{t-1}-0.38 L N \_X C H \_R A T E_{t-1}+5.9
\end{gathered}
$$

It should be noted that, similarly to the previous example, for the model of Polish economy, only equations of consumer price index (LN_CPI) and stock index (LN_FINDEX) are presented for illustrative purposes.

The analysis of the model's results reveals that the stock index (LN_FINDEX) is significantly impacted by the long-term relationship between variables (cointegration equation), while short-term shocks have almost no influence on values of the index. The main factors that influence the interest rate (LN_IRATE) are the values of the interest rate in the previous period. Money supply (LN_MSUPPLY) changes are driven by the following factors: lagged values of consumer price index, stock index, money supply, and exchange rate.

The conducted analysis of impulse response functions for Polish economy model indicates that after the shock of one standard deviation, most variables increase (decrease) after the second period and, as a result, each shock leads to permanent changes of the variables. The only exception is the stock index variable that, in case of the shock of one standard deviation, reverts to its initial state after two periods. An additional analysis of impulse response functions and variance decomposition graphs demonstrates that, for example, approximately $70 \%$ of exchange rate variation is explained by previous values of consumer price index, while the exchange rate explains only $20 \%$ of them.
Besides, the Granger test of variables under analysis for exogeneity revealed that the model of Polish economy has two exogenous variables: stock index and interest rate. These results can be explained by the fact that in countries with developing economies a stock exchange market is in the formation phase, so it does not have a significant influence on other variables; and the relation between stock index and monetary variables is not very significant as compared to developed economies.

In order to develop the econometric model to estimate the relationship between monetary and stock exchange variables for Ukrainian economy, a preliminary visual and diagnostic analysis of time series was conducted. The set of variables included: nominal exchange rate (ExchangeRate), currency and gold reserves of the National Bank of Ukraine (Reserves), inflation rate (Inflation); and PFTSI index (Index Price), the dynamic of which is presented in Fig. 2 . Testing the time series for stationarity takes to the conclusion that all time series under analysis are stationary in first differences (order of integration - 1), and there exists a cointegration relationship between them, which was confirmed by the Johansen test. That is why it has been decided to model the current relationship between the variables, using the vector errorcorrection model (VECM) consisting of 4 equations. The conducted test on the maximum lag length and lag exclusion test indicated that the optimal number of lags for the model of Ukrainian economy is three. 

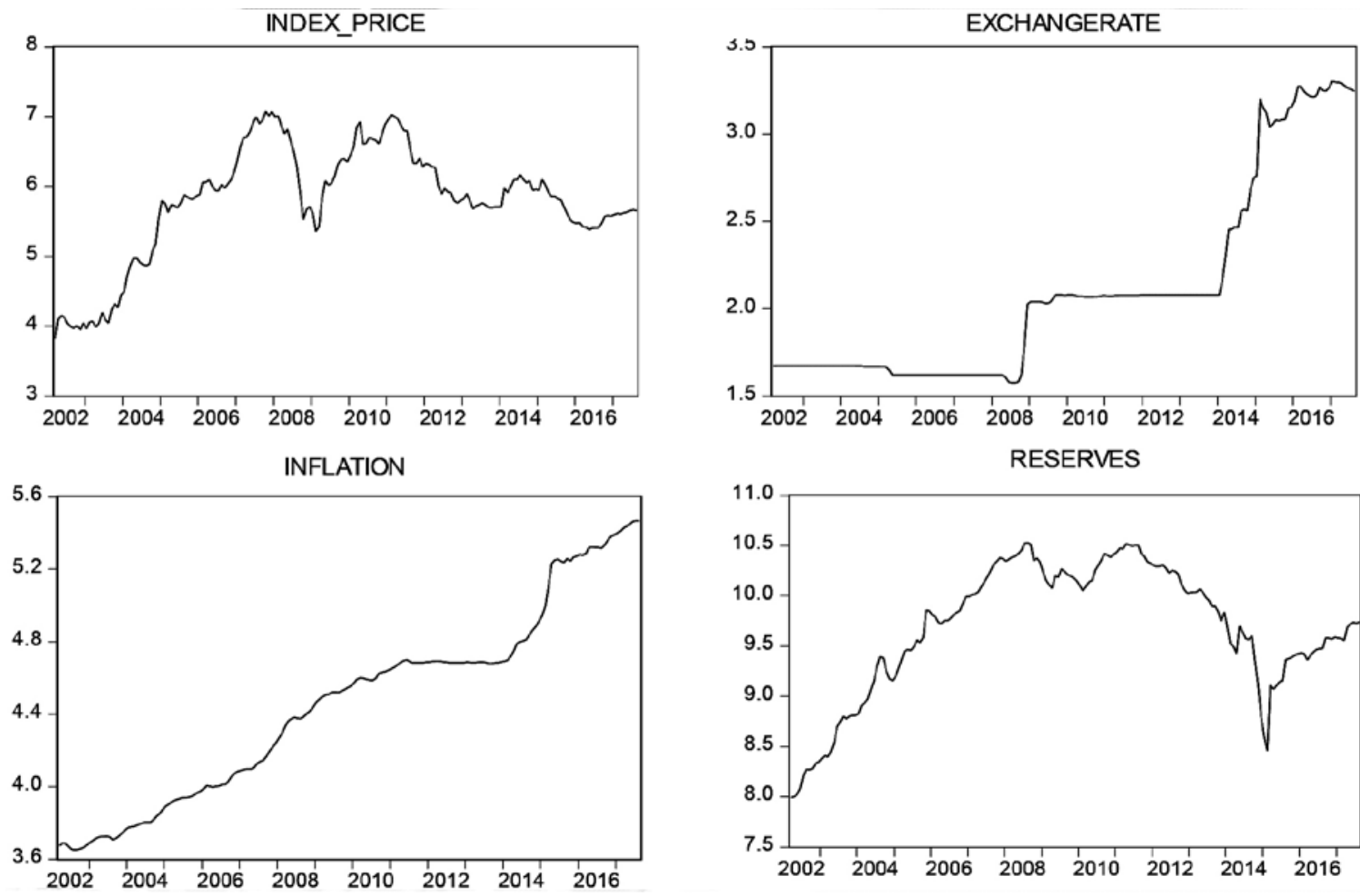

Fig. 2. The dynamic of times series for the model of Ukrainian economy during 2004-2017 of the following variables: PFTSI index (Index Price; IPrice), nominal exchange rate (Exchange Rate; ExRate), inflation rate (Inflation), currency and gold reserves (Reserves) (Source: developed by the authors based on the data from IMF's website)

The VECM model based on the actual data, which describes the interplay between monetary policy instruments and stock exchange indicators for the Ukrainian economy, is estimated in the following form $(t-$ statistics are presented in parentheses):

$$
\begin{aligned}
& \Delta\left(\text { IPrice }_{t}\right)=0.001-0.399 \Delta\left(\text { ExRate }_{t-1}\right)+1.438 \Delta\left(\text { Inflation }_{t-1}\right)+ \\
& (0.116)(-1.851)(1.604) \\
& +0.278 \Delta\left(\text { IPrice }_{t-1}\right)-0.327 \Delta\left(\text { Reserves }_{t-1}\right)-0.304 \Delta\left(\text { ExRate }_{t-2}\right)+ \\
& (3.595)(-2.822) \\
& (-1.230) \\
& +0.490 \Delta\left(\text { Inflation }_{t-2}\right)-0.086 \Delta\left(\text { IPrice }_{t-2}\right)-0.194 \Delta\left(\text { Reserves }_{t-2}\right)- \\
& (0.488)(-1.072)(-1.585) \\
& -0.423 \Delta\left(\text { ExRate }_{t-3}\right)+0.034 \Delta\left(\text { Inflation }_{t-3}\right)+0.091 \Delta\left(\text { Irrice }_{t-3}\right)- \\
& (-1.665) \\
& \text { (0.038) } \\
& -0.257 \Delta\left(\text { Reserves }_{t-3}\right)+0.328 \Delta\left(\text { ExRate }_{t-4}\right)-0.223 \Delta\left(\text { Inflation }_{t-4}\right)+ \\
& +0.143 \Delta\left(\text { IPrice }_{t-4}\right)+0.072 \Delta\left(\text { Reserves }_{t-4}\right)-0.054 \hat{u}_{1, t-1}- \\
& -0.294 \hat{u}_{2, t-1}
\end{aligned}
$$

$$
\begin{aligned}
& \Delta\left(\text { Inflation }_{t}\right)=0.006+0.074 \Delta\left(\text { ExRate }_{t-1}\right)+0.527 \Delta\left(\text { Inflation }_{t-1}\right)- \\
& \text { (5.828) (4.051) (6.915) } \\
& -0.013 \Delta\left(\text { IPrice }_{t-1}\right)+0.010 \Delta\left(\text { Reserves }_{t-1}\right)+0.073 \Delta\left(\text { ExRate }_{t-2}\right)- \\
& (-2.046) \\
& (0.975)
\end{aligned}
$$




$$
\begin{aligned}
& \left.-0.046 \Delta\left(\text { Inflation }_{t-2}\right)-0.006 \Delta\left(\text { IPrice }_{t-2}\right)-0.033 \Delta \text { (Reserves }_{t-2}\right)- \\
& (-0.543) \\
& (-0.911) \\
& \text { (-3.128) } \\
& -0.058 \Delta\left(\text { ExRate }_{t-3}\right)+0.018 \Delta\left(\text { Inflation }_{t-3}\right)-0.007 \Delta\left(\text { IPrice }_{t-3}\right)- \\
& (-2.686) \\
& \text { (0.235) } \\
& -0.001 \Delta\left(\text { Reserves }_{t-3}\right)-0.002 \Delta\left(\text { ExRate }_{t-4}\right)-0.089 \Delta\left(\text { Inflation }_{t-4}\right)- \\
& (-0.136) \\
& (-0.097) \\
& -0.005 \Delta\left(\text { IPrice }_{t-4}\right)-0.018 \Delta\left(\text { Reserves }_{t-4}\right)+0.009 \hat{u}_{1, t-1}+ \\
& (-0.746) \\
& (-1.756) \\
& +0.023 \hat{u}_{2, t-1}(5)
\end{aligned}
$$

where $\hat{u}_{1}, t-1, \hat{u}_{2}, t-1$ - equations of long-term equilibrium (cointegration equation), normalized by the

variablesIPrice andExRate that are represented as follows:

$$
\begin{aligned}
& \hat{u}_{1, t-1}=\text { IPrice }_{t-1}-0.070 \text { Inflation }_{t-1}-1.273 \text { Reserves }_{t-1}+6.861 \\
& \hat{u}_{2, t-1}=\text { ExRate }_{t-1}-1.180 \text { Inflation }_{t-1}-0.302 \text { Reserves }_{t-1}+0.233
\end{aligned}
$$

It should be noted that, similarly to two preceding models, only equations of consumer price index (Inflation) and stock exchange index PFTSI (IRate) from the general estimated model of Ukrainian economy are presented for illustrative purposes.

The analysis of the modelling results reveals that the change in gold and currency reserves is driven by the long-term relationship between variables (cointegration equation), the changes in exchange rate and reserves in the previous period, the exchange rate with the lag of two periods, as well as the inflation and reserves with lags of 4 periods. In the equation of inflation significant variables include the long-term relationship between variables, PFTSI index (lag 1), exchange rate (lags 1, 2 and 3), inflation (lag 1), and reserves (lag 2). The exchange rate is mainly impacted by PFTSI index (lag 3), exchange rate (lags 3 and 4 ), and reserves (lags 1, 2, and 3). The PFTSI index is primarily influenced by the values of the index itself in the previous period, reserves (lag 3), and long-term relationship between variables (cointegration equation).

The conducted analysis of variance decomposition graphs presented in Fig. 3 indicated that on average $55-90 \%$ of stock index variation is explained by previous values of the index PFTSI, approximately $15-30 \%$ by exchange rate. About $70-80 \%$ of inflation variation depends on the previous inflation values during 2-4 periods, and 30-40\% after the period 7; at the same time, approximately $50 \%$ of inflation variation is explained by changes in reserves starting from the tenth period. More than a half of exchange rate variation is driven by previous values of the exchange rate, about $50 \%$ - by the variation of reserves. The analysis of the reserves' variance decomposition revealed that this variable is weakly dependent on the variation of other monetary indicators during the first ten periods while after the 15 th period much more influence is exercised by exchange rate and stock exchange index, each explaining about $20 \%$ of reserves on average. It should be also mentioned that the proportions of the variables in the variations of other indicators are not constant. They are changing with the passage of time. It is mainly observed in the variace decomposition of the exchange rate and inflation (the share of reserves is increasing), reserves (shares of the exchange rate and PFTSI index are increasing), stock index (shares of the exchange rate and reserves are increasing).

The forecasting accuracy of the model is also quite high. According to the mean absolute percentage error criterion, the forecast of inflation has a $2 \%$ error, the forecast of reserves may deviate by $7 \%$, while the forecasts of exchange rate and stock index by $16 \%$ and $14 \%$ respectively.

Besides, the analysis of variables for exogeneity for the model of Ukraine using the Granger test revealed that the model has one weakly endogenous/ exogenous variable: PFTSI index (1\% level of significance), which is almost not influenced by other monetary variables. The obtained result is similar to the conclusions drawn from the model of Polish economy. In fact, in countries with transformational economies, the stock exchange market is still in the formation stage, so it has no significant influence on monetary indicators, contrary to the situation observed in developed countries.

Conclusions and further research proposals. The conducted analysis with using a system of VAR/VECM models for developed economies (the USA) and developing ones (Ukraine, Poland) confirmed the relationship between stock exchange indices and macroeconomic indicators, including monetary instruments, which coincides with the conclusions of most empirical studies, despite different time periods and countries, as well as different sets of variables included into the models. However, it has been revealed that the significance and sets of monetary variables influencing the performance of stock exchanges differ among countries depending on the level of their development. 
Variance Decomposition ofINDEX_PRICE

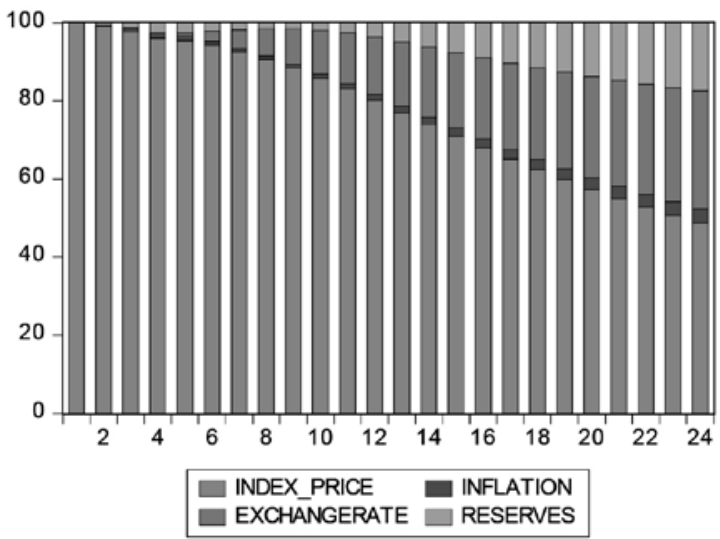

Variance Decomposition of EXCHANGERATE

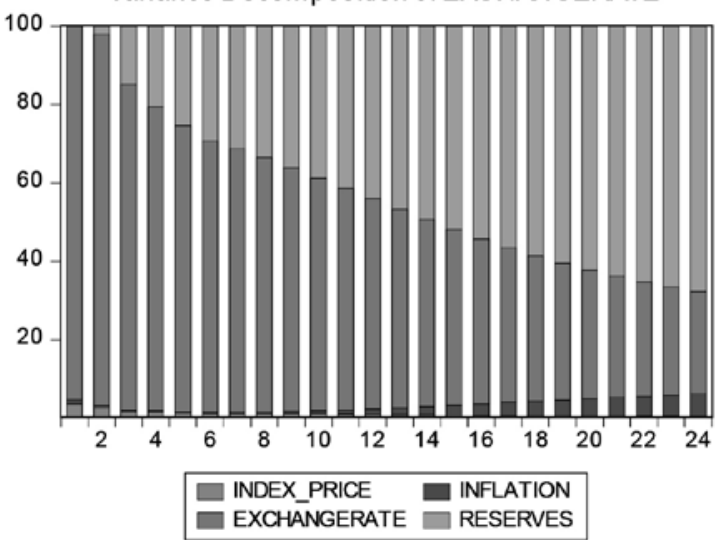

Variance Decomposition of INFLATION

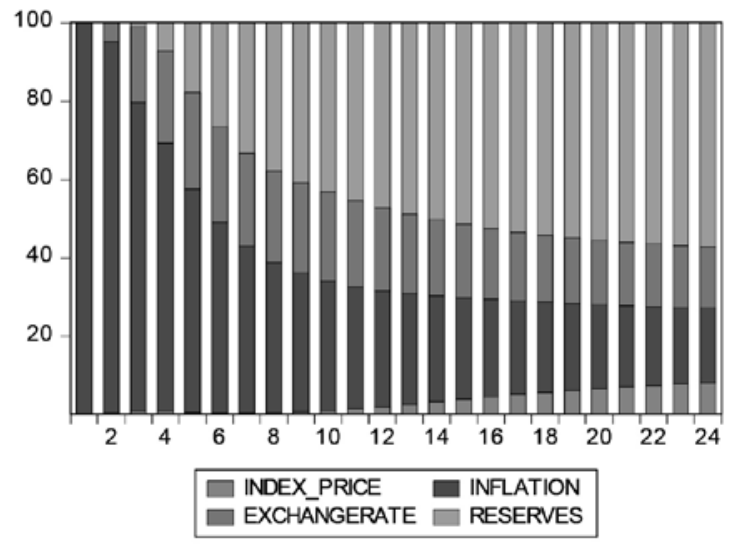

Variance Decomposition of RESERVES

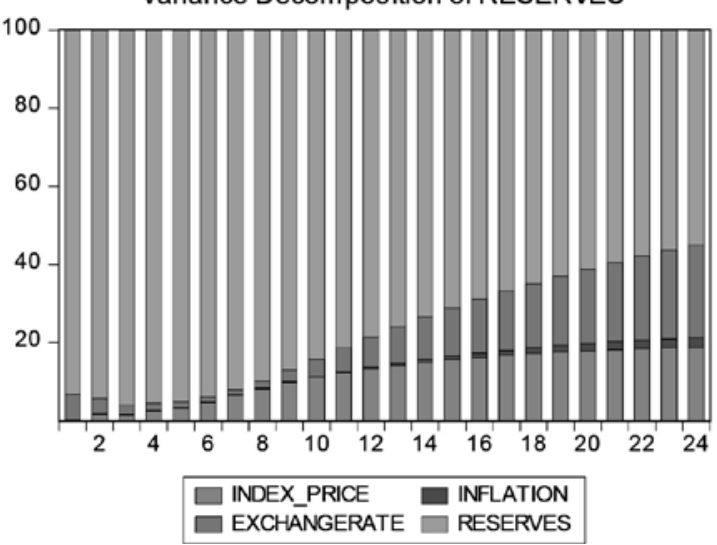

Fig. 3. Variance decomposition graphs of the following variables: PFTSI index (Index_Price), inflation rate (Inflation), nominal exchange rate (ExchangeRate), gold and currency reserves (Reserves) for the model of Ukrainian economy (Source: calculated by the authors)

In addition, based on the results of calculations using the developed econometric models, it was empirically confirmed (or partially confirmed) that most of the initial assumptions and hypotheses are true, in particular the assumption that a central bank and other regulators can actually influence the stock exchange indices using monetary policy instruments, but this influence is significant only on the markets of developed countries (for instance, the USA). However, in developing countries the stock index does not depend on short-term changes in monetary indicators, which reduces the regulator's influence on the stock exchange indices. At the same time, the stock index is the factor that has a significant impact on monetary indicators in both developed countries (the USA) and developing ones (Ukraine, Poland). Unlike the initial assumption, the largest influence on the stock index is exerted by lagged values of the stock index and reserves (in Ukraine) and the lagged values of the stock index itself and money supply (in developed countries), but not on the value of interest rates, as was expected before the research.
Taking into consideration the results of the current research, it can be concluded that in Ukraine with transformational economy, which is characterized by high economic and political risks, the monetary policy of state regulators is an ineffective instrument for influencing the capital markets' indicators. That is why other instruments of economic policy should be applied for gradual development of stock exchange markets in Ukraine. In particular, important factors of the development include: attraction of foreign investments, stabilization of the banking sector, industrial recovery, stimulation of affordable lending, the development of stock market infrastructure, etc. In addition, according to the research results, the development of stock exchange market positively influences the macroeconomic indicators of a developing economy. Therefore, it is highly important for Ukrainian policymakers to include such an aim as the development of effective and liquid stock market to the strategic plan of Ukrainian economy, which will not only help to attract foreign and internal investments but may also become one of the major factors of economic growth in mid- and long runs.

\section{References}

1. Hluschenko, S. (2016). Monetary strategies: threats of implementation in Ukrainian economy. Scientific papers NaUKMA. Economics, 1 (1), 35-42.
2. Klebanova, T. S., \& Ponomarenko V. S. (2015). Applied aspects of social and economic systems modelling. Berdiansk: Tkachuk A. V. 
3. Klymenko, K. (2015). Development of the Ukrainian stock market in the context of Eurointegration processes. Economy and the State, 8, 63-71.

4. Krasnova, I. (2014). Stock market in Ukraine: state and perspectives for development. Problems of the economy, 1, 129-134.

5. Skrypnychenko, M. (2015). Models for identification of macroeconomic disbalances in Ukraine. Institute for economics and forecasting. National Academy of Sciences of Ukraine.

6. Primierova, O. (2016). Peculiarities of stock exchange market development in Ukraine. Effective economy, 2916, (5).

7. Semko, R. (2012). The major approaches toward modelling stock market and real sector of economy. Scientific papers NaUKMA. Economics, 128, 80-85.

8. Lukianenko, I., et al. (2017). System analysis of state policy development during macroeconomic destabilization. Kyiv: NaUKMA.

9. Chernova, O., \& Popko, V. (2016). Analysis of contemporary world securities market. Economics. Management. Innovations. Series: Economic sciences, 2 (17), 403-415.
10. Shumska, S. (2015). Monetary policy and recovery of economic growth in Ukraine. Economics and forecasting, 3, 21-41.

11. Chaudhuri, K., \& Smiles, S. (2004). Stock market and aggregate economic activity: evidence from Australia. Applied Financial Economics, 14 (2), 121-129.

12. Cheung, Y. W., \& Ng, L. K. (1998). International evidence on the stock market and aggregate economic activity. Journal of empirical finance, 5 (3), 281-296.

13. Lee, B. S. (1992). Causal relations among stock returns, interest rates, real activity, and inflation. The Journal of Finance, 47 (4), 1591-1603.

14. Oseni, I. O., \& Nwosa, P. I. (2011). Stock market volatility and macroeconomic variables volatility in Nigeria: an exponential GARCH Approach. European Journal of Business and Management, 3 (12), 43-54.

15. Rad, A. A. (2011). Macroeconomic variables and stock market: evidence from Iran. International Journal of Economics and Finance Studies, 3 (1), 1-10.

Лук'яненко І. Г., Сова С. С.

\section{ЕМПІРИЧНЕ ОЦІНЮВАННЯ ВПЛИВУ МОНЕТАРНОЇ ПОЛІТИКИ НА ПОКАЗНИКИ ФОНДОВОГО РИНКУ}

Метою дослідження є емпіричний аналіз та розробка адекватного економетричного інструментарію оиінювання взаємозв 'язку між монетарними показниками й індексами фондових ринків для визначення ефективних інструментів монетарної політики на стимулювання розвитку фондового ринку в короткостроковій та довгостроковій перспективі. У процесі дослідження було використано загальнонаукові методи системного аналізу та синтезу, методи узагальнення, систематизаиії та групування даних, а також сучасний економіко-математичний інструментарій, зокрема методи векторної авторегресії.

Результати роботи. На основі проведеного поглибленого статистичного та емпіричного аналізу розроблено комплекс структурних векторних авторегресійних моделей оцінювання впливу монетарної політики на показники фондового ринку для розвинених країн; країн, щьо успішно розвиваються, і країн зі значними економічними та політичними ризиками з урахуванням їхніх економічних особливостей. Реалізація розробленого комплексу VAR/VEC моделей на реальній інформації дала змогу оцінити потенційні можливості державних регуляторів здійснювати вплив на розвиток фондових ринків для різних груп країн, а також визначити найбільш ефективні монетарні інструменти стимулювання розвитку фондового ринку з урахуванням дії внутрішніх та зовнішніх ризиків у короткостроковій та довгостроковій перспективах.

Результати дослідження можуть бути використані для формування управлінських рішень державними регуляторами щодо напрямів стимулювання розвитку фондових ринків різних груп країн, зокрема України.

Buсновки. На основі проведеного дослідження з використанням розробленого комплексу VAR/VECM моделей було емпірично підтверджено, що Центральний банк та інші регулятори, справді, можуть впливати на показники фондового ринку через інструменти монетарної політики, однак цей вплив $\epsilon$ значущим лише на ринках розвинених країн (наприклад США). Проте на ринках краӥн, щзо розвиваються, фондовий індекс не залежить від короткострокових змін монетарних показників, що зменшуе вплив регулятора на показники фондового ринку. Водночас показник фондового індексу є значущим фактором, що впливає на монетарні показники, як для розвинених країн (США), так і для країн, що розвиваються (Україна, Польща). Зважаючи на результати иьього дослідження, можна зробити висновок, ще в Україні, економіка якої ще перебуває у стадії трансформачії та характеризується значними політичними та економічними ризиками, монетарна політика регулятора є неефективним інструментом виливу на показники ринків капіталу. При иьому розвиток фондового ринку позитивно впливає на макроекономічні показники економіки, яка розвивається. Саме тому важливим елементом державної економічної політики Украӥни є розвиток ефективного й ліквідного фондового ринку, що може стати одним із факторів економічного зростання у середньо- $і$ довгостроковій перспективі.

Ключові слова: монетарна політика, фондовий ринок, макроекономічні показники, векторні авторегресійні моделі, механізм корегування помилки. 